\title{
Vietnam's Political Economy in Transition (1986-2016)
}

Quan-Hoang Vuong

Stratfor Worldview

Texas, May 27, 2014

\section{Stratfor WORLDVIEW"w}

https:// worldview.stratfor.com/article/vietnams-political-economytransition-1986-2016 


\section{Vietnam's Political Economy in Transition (1986-2016)}

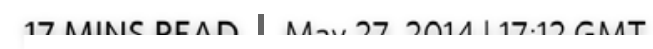

By Quan Hoang Vuong

The transition economy of Vietnam enjoyed remarkable achievements in the first 20 years of economic renovation (Doi MoI) from 1986 to 2006. Notably, the economy grew at an average annual rate of 7.5\% in 1991-2000 period. Vietnam's Amended Constitution 1992 recognized the role of private sector in the economy. U.S.-Vietnam Trade Bilateral Agreement (US-BTA) was 
signed in 2001. The country's stock market made debut trading in 2000. Vietnam became a member of Association of Southeast Asian Nations (ASEAN) in 1995, then proceeded to full membership of the World Trade Organization in 2007, following which registered foreign direct investment (FDI) reached an alltime high of US\$71.7 billion in 2008. Together with the impressive economic achievements, Vietnam also saw its diplomatic and political status constantly improved in the international arena. The country has established diplomatic relations with more than 170 countries in the world, strategic partnerships with 12 important economies, both developed and emerging, namely China, Japan, Russia, India, England, France, North Korea, Italy, Germany, Indonesia, Malaysia and Thailand. The country also successfully hosted important events including the Asia Pacific Economic Cooperation (APEC) in 2006.

Upbeat sentiment helped to send Vietnam's stock market index (VN-Index) to its peak of 1,170 in March 2007 before its nosedive to 250 in February 2009, auguring an imminent crisis. Since 2008 Vietnam's GDP pace of expansion has slowed down markedly, with 2012 rate declining to $5 \%$, the lowest level in 13 years, while the macro economy faced paramount turbulence, large trade deficit, high inflation, overwhelming business closures, rampant corruption and transparency problems, demonstrations of enraged citizens, downgrading environment, and sovereignty confrontation with China in the South China Sea (politically correct: "the East Sea”).

Since the world's geo-economics and geo-politics are entering an uncharted territory of evolving complication and rising 
uncertainty, not only Vietnamese entrepreneurs and households but also economists and policy makers are puzzled about what have happened, although the government has made a ten-year plan for 2011-20 socio-economic development. The ruling elites appear to have written this plan based more on "the desirable" than "the achievable" while a clear vision for farther future based on careful projections and profound solutions is needed.

Vietnamese and outsiders have been increasingly aware of noticeable gaps between the country's promising potential and actual realization (Napier and Vuong, 2013). As Vietnam has been considered somehow an entrance geopolitical game of East Asia and a 600-million population ASEAN market, the keen eye of international players sticks to the Vietnamese political economic scene of the country, which will most likely define the economic and diplomatic paths in the coming years.

\section{The four characteristic sub-periods of post-Doi Moi transition}

From the adoption of Doi Moi in 1986 by the CPV's Sixth National Congress to present day, Vietnam's economy has transformed from a centrally-planned model to market oriented with four characterized sub-periods. We divide the sub-periods based on the economy's entrepreneurial perspectives, emerging cultural values, the building of market economy, and attitude toward global geopolitics and economics.

The period of “entrepreneurial policy-makers” (1986-1994)

In its history, Vietnam barely had economic prosperity that lasted for decades. Until early twentieth century, the feudalist nation was a small and outdated agrarian country with continuous 
wars and invasions from the North (China and Mongolia) and conflicts with the Southwest neighbor (Cambodia). In the $20^{\text {th }}$ century, the French and American wars drew most national efforts to serve the combats. From the national unification in 1975 to 1985, the nation struggled with its five-year plans on collectivization of agricultural and industrial production. However, the real results were often far behind expectation because the guiding principles "violated the most important motivation for production development, that it is worked against the working people's vital vested interests," (Boothroyd and Pham, 2000).

Upon the failure of the 1985 price-wage-currency adjustment scheme, a severe economic crisis followed, resulting in hyperinflation of $775 \%$ in 1986 , scarcity of staples and consumer goods, impoverished living conditions, industrial stagnation, and mounting foreign debts (Pham and Vuong, 2009; Vuong, Dam, Van Houtte, and Tran, 2011). The situation worsened as Vietnam could barely trade with the West due to the U.S.'s trade embargo (Cockburn, 1994). The chaos had put the CPV under immense pressure to get the country out of the crisis, and Doi Moi policies were an answer introduced in 1986, with which Riedel and Turley (1999) believed that there was no "political revolution or ideological conversion on the part of the leadership.” The socialist ideology remained and was reiterated by the political leader of $D o i$ Moi, the Communist Party of Vietnam (CPV) General Secretary Nguyen Van Linh that "It is not objectively necessary to establish a political mechanism of pluralism and multiparty government. Socialism is the only right decision" (Shenon, 1998). 
However, Doi Moi leaders demonstrated some remarkable entrepreneurial characteristics in their economic thinking and implementation (Vuong et al., 2011) as "economic crisis and harsh realities were neither necessary nor sufficient conditions for the reform to take place" which enabled an undertaking process that had brought about the long-awaited extensive reforms, learning lessons of economic policies from Ho Chi Minh's times, 1945-1969, about the adoption of a multi-sectoral economy based on different types of ownership, encouraging for foreign investments, foreign trade (Pham and Vuong, 2009; Vuong et al., 2011).

Before Doi Moi, Le Duan, CPV General Secretary from 1960 to 1986, was already critical of economic models taught by the Soviet Union and China for chronic economic malaise and blunders, although despite some innovative thinking Le Duan himself was a strong opponent of market economy and much of his policy turned out counter-productive. But in his time, Kim Ngoc, Party Secretary of Vinh Phuc province from 1966 to 1967, was an accomplished entrepreneurial politician who soon recognized problems of the mass collectivization, which resulted in poor agricultural production, and the need to have property right in farm household. He 'invented' a pilot plan called Khoán, which had granted a certain degree of economic freedom to farmers, leading to remarkably higher rice yield and pig herds during the American war. Ngoc's innovative ideas were basically not accepted by the North's collectivism, and for a moment was regarded as an offensive to the prevailing socialist ideology (Vuong et al., 2011).

After the death of Le Duan, Truong Chinh, a high-ranked politburo member and who would then briefly serve as CPV 
General Secretary (July-December 1986), was another highly influential leader and "the one who laid down the first brick for the House of Reform of Vietnam," (Vuong et al., 2011) by launching the program of extensive reforms during the $6^{\text {th }}$ CPV Congress in December 1986. As Truong Chinh stepped down, Nguyen Van Linh, CPV General Secretary 1987-91, continued to bring concepts of reforms to the nation's economic life through a nationwide reform program with sweeping changes (Tran, 2002). The oldfashioned centrally-planned economy was replaced with socialist market mechanism, which promoted the concept of a multisectoral economy, open-door policies towards international trade and investment, and recognized private property rights (Vuving, 2012).

The new Law on Foreign Investment initiated in 1987 enabled a surge of the first wave of foreign direct investments (FDI) flowing into Vietnam, which then reached 10\% of GDP in 1994. Vietnam was the largest FDI recipient among developing countries and economies in transition in proportion to the size of its economy (World Bank, 1999) thanks to its "macroeconomic stabilization resulting from Doi Moi and investor expectations of continuing reforms and improvements in the general investment climate" (Kokko, 1998). Corporate Law and Private Enterprise Law in 1990 'broke ground' the national private growth engine. From the old Confucian view imposed by the feudalist elites, which favors "educated scholars serving the government" (Vuong and Tran, 2009), by 1994 over 17,400 entrepreneurial firms started up. The 1992 Constitution extended human rights and recognized the multi-sectoral economy.[i] Land Law in 1987 (revised in 1993) 
granted farmers land use rights. The milestones of Doi Moi from 1987 to 1994 can be summarized in the following table.

Vietnam quickly grew to become the world's third largest rice exporter in 1989 (approx. 1.2 million tons exported), after China and the United States. The entrepreneurial policy-makers had been the core element to bring about change in macroeconomic management in 1990s although the CPV reserved status quo as the unique ruler.

\section{Economic integration and adaption of market economy} (1995-1999)

An eminent reformer, Prime Minister Vo Van Kiet came in office from 1992 to 1997, and continued to advocate extensive reforms. Vietnam sought further economic integration and diplomatic relations within the region and the world. From 1995 to 1999, the normalizing of diplomatic and trade relations with the United States was among the most remarkable for Vietnam, opening up opportunities to work with the world's developed economies and international organizations around, including multi-lateral donors such as the World Bank and ADB.

While the conservative in the CPV may have been afraid of losing their control over economic development and the national politics, generally speaking the CPV adopted open policies as they saw benefits for the country while no direct threats to their power were seen. Despite existence of conflicting views within the CPV, Doi Moi momentum was retained for almost two decades with political consensus over three major principles: a) Political stability is a prerequisite of economic development, and the CPV remains to be the unique power; b) To achieve economic goals, 
Vietnam must keep its door open to foreign trade and investment; and, c) Gradualism is preferred to avoid 'deviation from the socialist path' (Riedel and Turley, 1999). These principles have been preserved and implemented explicitly through the CPV and government's socio-economic and foreign policies.

The U.S. also had some commercial interest in Vietnam's growing economy and strategic political interest to work with allies and friends "to promote stability and development by integrating Vietnam more fully into the existing East Asian order," (U.S. Congress, 2005). Over US $\$ 10$ billion of FDI entered the country in 1996 together with billions of dollars of ODA coming from the World Bank and Asian Development Bank. FDI enterprises played an important role in creating jobs (Athukorala and Tran, 2012), paying corporate taxes, encouraging consumption and competition, and contributing to export growth (Nguyen and Xing, 2008). Vietnam's GDP grew at 9.5\% and 9.3\% annually in 1995 and 1996 respectively, the highest rates recorded in the post-Doi Moi period.

The country also expanded its diplomatic relations within the region becoming member of ASEAN (1995), APEC (1998). The U.S. and Vietnam then expanded the relation into a US-Vietnam bilateral trading agreement (the BTA was later signed in 2001). The US-Vietnam BTA "had an important political economy impact” by “spurring political will to speed up negotiations on [Vietnam's] accession to WTO” in later years (CIEM-USAID, 2007).

Integrating in international markets has brought about new market opportunities and helped the country to deepen its reform, but at the same time exposed the country to contagious 
risks. Although less hurt by the Asian financial crisis in 1998 than other major Asian economies due to its young markets, Vietnam experienced GDP growth decline to $4.77 \%$ in 1998 and committed FDI fell by half in 1997-1998 to approximately US $\$ 5$ billion, compared to US $\$ 10$ billion in 1996 (Vuong, 2010). When the Asian financial turmoil broke out, Vietnam was still a nascent market model, without stock market; and the fledgling banking system was controlled by the state-run powerhouses who occupied $75 \%$ of assets and credit portfolio (Kokko, 1998). Inefficient SOEs still accounted for $50 \%$ of the country's output (Congress Research Service, 2005).

Economic boom and emerging cultural values (2000-2006)

Succeeding Vo Van Kiet, Prime Minister Phan Van Khai (1997-2006) continued to pursue further integration into the world economy, especially from 2000 to 2006. In 2005, Mr. Khai was the first Vietnamese leader visiting the U.S., strengthening diplomatic relations between the two countries. The U.S. then supported Vietnam's accession to WTO in early 2007 (Congress Research Service, 2008). Under Khai's leadership, Vietnam's economy experienced economic prosperity, quickly expanding financial markets and GDP, low inflation, surging FDI inflows and faster pace of privatization of SOEs. The capitalist symbolic finance machine - the stock market - was born in July 2000.

By the end of 2000, Vietnam stock market's capitalization was negligible in economic terms, less than $1 \%$ of GDP. But by the end of 2006 , the figure rose to $22.7 \%$. In $2006 \mathrm{VN}$-Index rose $150 \%$. From 2006 to early 2007, investors considered stock markets a 'money machine,' and herd mentality triggered huge market 
bubble risks. Despite immense risks, the market continued to go high as capital gains were still made easily, and macro prospects looked bright with Vietnam joining WTO soon (Pham and Vuong, 2009).

An average GDP growth of $7.5 \%$ in $2000-2005$ period and the economy ranked at 58th largest in the world in 2006 made Vietnam like a little tiger economy in Southeast Asia (GSO, 2011; UNCTAD, 2008). However, the rapid rate succumbed to 'resource curse' problem (Vuong and Napier, 2014) as there appeared more evidence that economic growth heavily relied on overconsumption of physical assets or/and capital endowments while innovation and productivity were not the main emphasis, leading to a decline of competitiveness. Vietnam's high incremental capital to output ratio (ICOR) of 7-8 times, compared to other Southeast Asian economies of 3-4, and rising investment to GDP over years, i.e., $4.9 \%$ (from 1996 to 2000 ) to $39.1 \%$ (2001-2005) to the staggering $43.5 \%$ (2006-2010) show its propensity to consume more resources while seeking growth. The absence of innovation and creativity together with resource curse will be destructive in the long run. Worse, the curse is more severe in the state-owned sector whose ICOR is two or three times higher than that in non-state sector.

Under P.M. Phan Van Khai's leadership, although the state-led model was still advocated, he did not vow to establish the staterun conglomerates. (There were only two state-run conglomerates established under Khai's tenure that are Vinacomin and Vinashin.) In a stark contrast, his successor P.M. Nguyen Tan Dung established other eleven conglomerates within a few years after he 
took office. The breakdown of investment capital of the stateowned behemoths (Table 1) showed remarkably greater state budget investment in SOEs in 2008-09.

Still, combining the rapid growth and booming markets, Vietnam was successful in reducing poverty rate from $28.9 \%$ in 2002 to $18.1 \%$ in 2004 and $15.5 \%$ in 2006 (GSO, 2011). Inflation was kept under check with average CPI in the period at $4.5 \%$, a remarkable achievement as inflation has always been a chronic disease of the post-Doi Moi period.

The US-Vietnam BTA and investors' projections that Vietnam would enter WTO in 2006 and China plus one strategy (Shimizu, 2007) contributed to make Vietnam an attractive destination for FDI (UNCTAD, 2008: 8). Political and social stability played a significant role in facilitating economic development and attracting FDI (Dapice, 2003). FDI started to recover from 2003 (US $\$ 3.2$ billion registered capital) to 2006 (US $\$ 12$ billion), generating growth and employment.

Privatization (politically correct: ‘equitization') of SOEs also saw improvement in the 2002-06 period with 2,813 enterprises being privatized, compared to a handful in 1990s, 60 in 2011, and 16 from 2012 to 2013Q1 (Bao Hai Quan, 2013).

Globalization and attitudes toward global geopolitics and geoeconomics (2007-present)

After two decades of growth, the engine started to lose its steam in late 2000s. The contemporary state-run conglomerate model has shown serious problems ranging from poor efficiency and corruption to crony capitalism. The macro economy again experienced a period of high inflation, budget deficit, declining 
foreign exchange reserve, mismanaged fiscal and monetary policies, high unemployment and sluggish commercial activities.

Vietnam's unstable macroeconomics with two-digit inflation in 2008 together with spillover effect of the global crisis had made the stock bubble burst in 2009. The VN-Index went down to less than 250 in February 2009 from the peak of 1170 in March 2007; and it has never regained the expected 600-point level that experts, policy makers and investors had desperately looked for while the downtrend became unavoidable in mid-2008 (Pham and Vuong, 2009).

In a more complex financial system with interconnected stock markets, real estate markets and money market, the problems do not just stay with stocks. Vuong and Nguyen (2008) argued that there was an interconnectedness between Vietnamese stock market, properties market and money market, showing rising complexities. After the boom of stock market and skyrocketing stock prices, many realized capital gains and speculated on real properties. This had led to a boom on real estate market from 2007 to 2010 where home prices went exponential. A free fall in prices by almost $30 \%$ in $2012 \mathrm{Q} 2$, coupled with no liquidity, made speculators panic (Vuong 2012). The continuous fall of property prices by another $30 \%$ in $2013 \mathrm{Q} 2$ killed most speculators and developers. The government admitted that VND 108 trillion (\$5.1 billion) worth of real property become non-tradable in the second quarter of 2013 (Vietnamnet, 2013).

The banking sector immediately suffered, as about $50 \%$ of credits had been extended to real estate speculations and developments (Hong Suong, 2013a). Bad debts mounted, stifling 
credit flows to the economy and dragged production, businesses and consumption. Tightened banking credits then triggered informal credits and hyperactivity of 'loan sharks' to the extent that the government was worried about social unrest caused by rampant financial failures in information economy and households. Government's stimulus package of US\$8 billion in 2008 and 2009 had temporarily backed GDP growth at $6.78 \%$ in 2010 before inflation threat became real in 2011. The growth rate fell to $5.03 \%$ in 2012, the lowest within 13 years (Nguyen, Nguyen and Nguyen, 2010). From 2011 to 2012, the economic crisis has pushed approx. 100,000 firms out of business, $\sim 20 \%$ of the enterprise population (Vuong, 2012). Consumer price index (CPI) only slowed down in the recent years as a result of falling domestic demand.

From 2007 to present, the government's policies to use state-run conglomerates as the chief force to propel Vietnam's economy have degraded into problems of crony capitalism, interest groups and corruption, which induce rent-seeking and exacerbate the 'resource curse' problem in Vietnam. The state sector only creates $10 \%$ employment but consumes $70 \%$ total social investment, $50 \%$ total state investment, $60 \%$ commercial credit, and $70 \%$ of ODA (BBC, 2013).

The problems prevailed in banking industry and other essential industries of the country. A typical example is tycoon Nguyen Duc Kien, a senior commercial banker, who had manipulated the banking industry and gold market before being arrested in August 2012. His arrest sent a chill through the Vietnamese stock markets for three consecutive days, during which most stocks lost $20 \%$ of 
their value, and almost created a bank run at ACB that forced the State Bank to directly inject liquidity into the bank (Nguyen, 2012). Many state-run conglomerates, the government's expected to be their 'iron fists,' now turned out to be debt-stricken patients generating overwhelming losses, debt burdens or scandalous corruption worth billions of U.S. dollars, i.e. Vinashin, and Vinalines, Vietnam Electricity Group (EVN), Vietnam National Coal and Mineral Industries Group (Vinacomin). In Vietnam, when the rule of law does not catch up with the expansion of the financial sector, political connections are used to channel loans toward unprofitable sector, hindering impact of finance on investment growth (Malesky and Taussig, 2009).

Although Vietnam's GDP per capita reached US $\$ 1,555 /$ year in 2012 and $\$ 1,700$ in 2013, the new millennium's setting is far different from that of the 1990s (Dan Tri, 2013). Vietnam is now part of the world's bigger game, in which it has passed the point of no return. The economy has been becoming more open and engaged in international affairs. Vietnam has started to acquire important positions in United Nations and shown its interest in world geopolitical issues by joining the UN Peace Keeping Operation in early 2014. Vietnam's participation is prepared with the help of the United States, who supports the UN operation by its Global Peace Operation Initiative. The country's joining into UN peace keeping force may potentially open new possibilities for U.S.-Vietnam relation, a meaningful event in global geopolitics (Wilson 2013). The CPV and the government have tried to preserve political stability through domestic policies (despite the successes and failures) and seeking foreign supports via foreign relations. 
For these hard, expensive and painful lessons about market mechanism and ideology, the 'little tiger' has not roared yet.

\section{Subscribe to Intelligence Over News}

Independent Strategic Analysis | Objective Geopolitical Insights

\section{Start your subscription today!}

\section{Article Search}

\#

A Year On, China's Tech-Focused

Stock Market Is Making Strides

viuniry vur

2020 Annual

iu vouvisy

Forecast as

Rundown:

2021

Unrest in

Nigeria, More

Approaches

Brexit Talks

Copyright (c) Stratfor Enterprises, LLC. All rights reserved. 


\section{References}

ADB. 2011. "Natural Disasters and Damage Caused By Disaster In Vietnam," Water Sector Review Project ADB TA-4903-VIE.

Anh Hong. 2012a. "Cocacola lien tuc bao lo: dau hieu bat thuong," [Cocacola continously reports losses: unusual sign], Tuoi tre, http:// www.tienphong.vn/Kinh-Te/ 603892/ Coca-ColaVN-lien-tuc-baolo-dau-hieu-bat-binh-thuong-tpol.html (accessed December 26, 2013).

Anh Hong. 2012b. "Them nghi an Metro lo" [Doubted Metro with loss], Tuoi Tre, http:/ / tuoitre.vn/ kinh-te/524353/ them-nghi-an-metro-lo.html\#ad-image-0 (accessed Dec. 26, 2013).

Athukorala, Prema-chandra, and Quang Tien Tran. 2012. "Foreign direct investment in industrial transition: the experience of Vietnam,"J ournal of the Asia Pacific Economy, 17(3).

Bao dien tu Dang Cong San Vietnam. 2010. “Doanh nghiep tu nhan dong gop 48\% vao GDP nam 2010," [Private sector contributed 48\% GDP in 2010], Dangcongsan, 24 Dec. http:// dangcongsan.vn/CPV/ Modules/News_English/News_Detail_E.aspx?CN_ID=44 0055\&CO_ID=10004 (accessed 26 Dec 2013).

Bao Hai Quan. 2013. “Co phan hoa DNN 20 nam [Equitizing state-owned enterprise the past 20 years]," http:// www.baohaiquan.vn/ pages/ cophan-hoa-dnnn-hon-20-nam-van-roi.aspx (accessed 15 October 2013).

BBC. 2013. "VN can ho tro doanh nghiep tu nhan [Vietnam needs to support private firms]," BBC Tieng Viet, http:// www.bbc.co.uk/vietnamese/vietnam/2013/ 12/ 131203_hsbc_vietnam_economy_ report.shtml (accessed December 26, 2013).

Bich Diep. 2013a. "Thu nhap dau nguoi cua Vietnam dat 10.000 USD trong thap ki toi" [Vietnam GDP per capita reach $\$ 10,000$ in next decade], Dan Tri, http:// dantri.com.vn/ kinh-doanh/thu-nhap-dau-nguoi-cua-viet-nam-dat-10000-usdtrong-thap-ky-toi-702455.htm (accessed October 16, 2013).

Bich Diep, 2013b. "Tin dung den o Vietnam xap xi 30\% tin dung ngan hang" [Vietnam's black credit equals roughly 30\% bank formal credit], Dan Tri, http:// dantri.com.vn/ kinhdoanh/ tin-dung-den-o-viet-nam-xap-xi-30-tindung-ngan-hang-789839.htm (accessed October 24, 2013).

Boothroyd, Peter, and Xuan Nam Pham. 2000. Socioeconomic renovation in Viet Nam: The origin, evolution, and impact of doi moi. Eds. Singapore: International Development Research Centre.

Büthe, Tim, and Helen V. Milner. 2008. "The politics of foreign direct investment into developing countries: increasing FDI through international trade agreements?" American J ournal of Political Science, 52(4): 741-746. 
Breu, Marco, Brian Salsberg, and Thanh Tu Ha. 2010. Growing up fast: Vietnam discovers the consumer society. McKinsey \& Company,

http:// www.mckinsey.com/insights/marketing_sales/growing_up_fast_vietnam_disco vers_the_consumer_society (accessed November 28, 2013).

Cain, Geoffrey. 2014. "Kill one to warn one hundred: The politics of press censorship in Vietnam," The International J ournal of Press/ Politics 19(1), 85-107.

Cockburn, Patrick. 1994. “US finally ends Vietnam embargo,” Independent, 4 February, 1994, http:// www.independent.co.uk/ news/ world/ us-finallyends-vietnam-embargo1391770.html (accessed December 5, 2013).

Central Institute of Economic Management and the U.S. Agency for International Development. 2007. Assessment of the Five-Year Impact of the U.S.-Vietnam BTA on Vietnam's Trade, Investment, and Economic Structure. Hanoi: National Political Publishing House.

Congressional Research Service. 2005. The Vietnam-U.S. Normalization Process. Washington: United States Congress.

Congressional Research Service. 2008, U.S.- Vietnam Relation Background and Issues for Congress, 2008, Washington: United States Congress.

Dan Tri. 2013a. "Thu nhap dau nguoi Vietnam dat 10.000 USD trong thap ky toi," [Vietnamese per capita income to reach $\$ 10,000$ in the next decade], Dan Tri, 3 March.

http:// dantri.com.vn/ kinh-doanh/ thu-nhap-dau-nguoi-cua-vietnam-dat-10000-usdtrong-thap-ky-toi-702455.htm (accessed 16 Oct 2013).

Dan Tri. 2013b. "Tin dung den o Vietnam xap xi 30\% tin dung ngan hang" [Vietnam's black credit equals roughly $30 \%$ bank formal credit], Dan Tri, 14 October.

http:// dantri.com.vn/ kinh-doanh/ tin-dung-den-o-viet-nam-xapxi-30-tin-dung-nganhang-789839.htm (accessed 24 Oct 2013).

Dao, Tuan. 2013. 'Tien le Dung Io voi'” [The precedence of Dung lo voi'], Lao Dong, http:/ / laodong.com.vn/ su-kien-binh-luan/ tien-le-dung-lo-voi-147429.bld (accessed J anuary 2, 2014)

Dapice, David O. 2003. Viet Nam's Economy: Success Story Or Weird Dualism? A SWOT Analysis, United Nations Development Programme, http:// www.hks.harvard.edu/mrcbg/research/d.dapice_cbg_Weird\%20Dualism_full\%2 0paper_PDF.pdf

Ebbinghausen, Rodion. 2012. "Vietnam's fragile middle class," DWAsia, http:// www.dw.de/ vietnams-fragile-middle-class/ a-16459275 (accessed November 28, 2012).

Economic Committee of the National Assembly (ECNA). 2012. Bao cao kinh te vi mo 2012: Tu bat on vi mo den con duong tai co cau [Macroeconomic Report 2012: From macro instability to restructuring road], Hanoi: Vietnam's National Assembly. 
Foreign Investment Advisory Service. 2003. Vietnam: Attracting More and Better foreign direct investment (Washington, DC: World Bank, 1999), in Ari Kokko, Katarina Kotoglou, and Anna Krohwinkel-Karlsson, "The implementation of FDI in Viet Nam: an analysis of the characteristics of failed projects," Transnational Corporations, 12(3).

Fritzen, Scott. 2002. "Growth, inequality and the future of poverty reduction in Vietnam," J ournal of Asian Economics, 13(5).

Gasiorowski, Mark J . 1995. "Economic crisis and political regime change: An event history analysis," American Political Science Review, 89(4): 882-897.

GSO. 2011. Tinh hinh kinh te-xa hoi Vietnam muoi nam 2001-2010, [Vietnam's Socio-Economic situation from 2001 to 2010], Hanoi: Vietnam Government.

GSO. 2012. Statistics on cumulative FDI values by investors. Hanoi: Vietnam Government, http:/ / www.gso.gov.vn/ default.aspx?tabid=392\&idmid=3\&ItemID=14344 (accessed October 13, 2013).

Vuong, Quan Hoang, and Tri Dung Tran. 2009. "The cultural dimensions of the Vietnamese private entrepreneurship." The IUP J ournal of Entrepreneurship and Development, 6(3/4), 54-78.

Hong Suong. 2010. "Bat dong san, vung trung tin dung ngan hang” [Real estate, 'sunken area' of bank credit], Sai Gon Tiep Thi, http:/ / zsgtt.vn/ Kien-trucdoi-song/ Chi-tiet/ 111927/ Batdong-san-\%E2\%80\%9Cvungtrung\%E2\%80\%9D-tin-dung-ngan-hang.html (accessed October 16, 2013).

Howard, Marc Morjé. 2002. "The weakness of post communist civil society,"J ournal of Democracy, 13(1).

IMF. 2013. Vietnam Total Investment, Percent of GDP. http:/ / www.quandl.com/IMFInternational-Monetary-Fund/ NID_NGDP_582-Vietnam-Total-investment-Percent-ofGDP (accessed December 1, 2013).

IMF Fiscal Affairs Department. 2012. Tax reform in Vietnam Issues for 2011-2015. Washington: IMF.

Import Administration Department (United States Government). 2002. Decision on Inspection No. A-552-801. Hanoi: United States Embassy in Vietnam, http:// vietnamese.vietnam.usembassy.gov/ bta_nmedecision.html (accessed October 9, 2013).

Intellasia. 2012. "Sweden to halt ODA funding to Vietnam," 23 April. http:// www.intellasia.net/ sweden-to-halt-oda-funding-to-vietnam-195274 (accessed 26 November 2013).

Keynes, J ohn Maynard. 2006. General theory of employment, interest and money. New Delhi: Atlantic. 
Kokko, Ari. 1998. “Vietnam: Ready for Doi Moi II?” ASEAN Economic Bulletin, 321.

KPMG Advisory China. 2012. The rise of the middle class in Asian emerging markets. KPMG.

Krueger, Anne O. 1974. "The political economy of the rent-seeking society," The American Economic Review, 64(3).

Le, Duan. 2007. Tuyen tap I, 1950-1965 [Selected Writings I, 1950-1965]. Hanoi: National Political Publishing House.

Lehrer, Jim. 1998. “Opening the door to North Korea,” PBS, http:// www.pbs.org/ newshour/ bb/asia/jan-june98/kim_6-9.html (accessed October 8, 2013).

Liu, Amy Y.C. 2001. "Markets, inequality and poverty in Vietnam," Asian Economic J ournal, 15(2).

Luong Bang. 2013. “Co phan hoa DNNN: Hon 20 nam van roi,” Bao Hai quan, http:// www.baohaiquan.vn/ pages/ co-phan-hoa-dnnn-hon-20-nam-vanroi.aspx (accessed October 15, 2013).

Mauro, Paolo. 1997. “Why worry about corruption,” Economic Issues, 6: 4-6.

Nam Phong. 2013. "Tien mac ket, BDS con sa lay" [Money got stuck, Property bogging down], Vietnamnet, http:/ / vietnamnet.vn/ vn/ kinhte/ 139149/ tien-mac-ket--bds-con-salay.html (accessed 15 October 2013)

Malesky, Edmund J., and Markus Taussig. 2009. "Where Is Credit Due? Legal Institutions, Connections, and the Efficiency of Bank Lending in Vietnam," J ournal of Law, Economics, and Organization, 25(2).

Ministry of J ustice. 2013. He thong van ban phap luat [Directory of regulations]. Vietnam Government, http:// moj.gov.vn/ Pages/vbpq.aspx?fromyear=2001\&toyear=2010 (accessed October 10, 2013)

Ministry of Planning and Investment. 2013. Hoi nghi tong ket 25 nam thu hut dau tu truc tiep nuoc ngoai tai Vietnam [Conference: Summary of 25 years in attracting FDI in Vietnam], Hanoi: Vietnam Government.

Napier, K. Nancy, and Quan Hoang Vuong. 2013. What We See, Why We Worry, Why We Hope: Vietnam Going Forward. Boise State University CCI Press.

National Financial Supervisory Commission (NFSC). 2011. Summary of Vietnamese stock market in 2011. Hanoi: Vietnam Government, http:// nfsc.gov.vn/ dinh-che-taichinh/ tong-quan-thi-truong-chungkhoan-viet-nam-2011 (accessed October 23, 2013).

Nhat Linh. 2006. "TTCK bung no, cac co phieu len san o gia ngat nguong," [Stock market booms; Sky-high stock debuts], Vinacorp, http:// www.vinacorp.vn/ news/ttck-bung-no-cac-cophieu-len-san-o-giangat-nguong/ ct-295629 (accessed October 15, 2013) 
Nguyen, Hoang Minh. 2012. "Ngan hang Nha nuoc dam bao thanh khoan cho ACB" [State Bank guarantees liquidity for ACB], Thanh Nien, http:/ / www.thanhnien.com.vn/ pages/ 20120822/ ngan-hang-nha-nuocdam-bao-thanhkhoan-cho-acb.aspx (accessed December 26, 2013).

Nguyen, Hung. 2013. "Tong Bi Thu: de phong the luc muon xoa bo Dieu 4 Hien phap" [General Secretary: watch out forces wanting to erase Art. 4 in Constitution], VnExpress, http:/ / vnexpress.net/ tin-tuc/ xa-hoi/ tong-bi-thude-phong-the-luc-muon-xoa-bo-dieu-4hien-phap-2886937.html (accessed October 9, 2013).

Nguyen, Huu Minh, Tony Cavoli, and J ohn K. Wilson. 2012. "The Determinants of Inflation in Vietnam, 2001- 09," ASEAN Economic Bulletin, 29(1).

Nguyen, Ngoc Anh, Duc Nhat Nguyen, and Thang Nguyen. 2010. "Current global crisis, fiscal stimulus package and implication for Vietnam,” Depocen Working Paper No. 2010/ 10.

Nguyen, Thanh Xuan, and Yuqing Xing. 2008. "Foreign direct investment and exports The experiences of Vietnam," Economics of Transition, 16(2): 183-197.

Nguyen, Tran Phuc, and Duc Tho Nguyen. 2009. “Exchange rate policy in Vietnam, 1985-2008," ASEAN Economic Bulletin, 26(2).

O'Reilly, Brendan. 2013. “China-Vietnam: more carrot, less stick,” Asia Times, http:// www.atimes.com/atimes/Southeast_Asia/SEA-01-221013.html (accessed : 28 Nov 2013).

Oxfam. 2013. Food prices: a looming crisis? http:// www.oxfam.org/ en/grow/ campaigns/agriculture/food_prices (accessed December 1, 2013).

Painter, Martin. 2003. "Public administration reform in Vietnam: problems and prospects," Public Administration and Development, 23(3): 259-271.

Pham, Minh Chinh, and Quan HoangVuong. 2009. Kinh te Viet Nam: Thang tram va Dot pha. Hanoi: National Political Publishing House

Pham, Thi Tuong Vi, and A. Terry Rambo. 2008. "Environmental consciousness in Vietnam," Southeast Asian Studies, 41(1).

Politburo. 2005. Resolution no. 48-NQ/TW, 2005, Hanoi: Vietnam Communist Party.

PWC. 2011. Transfer pricing and developing countries. European Commission.

Riedel, J ames, and William S. Turley. 1999. "The Politics and Economics of Transition to an Open Market Economy in Viet Nam," OECD Working Paper, No. 152

Shenon, Philip. 1998. “Nguyen Van Linh, Vietnam's Ex-Party Chief, Dies at 82,” The New York Times, http:/ / www.nytimes.com/ 1998/ 04/28/ world/ nguyen-van-linh-vietnams-exparty-chief-dies-at-82.html?src=pm (accessed December 23, 2013). 
Shimizu, Kaho. 2007. "Alternative to China J apanese Firms Flock to Booming Vietnam," J apan Times, http:// sites.google.com/site/ vietnamhuy/Vn_japanflock_JT_0705.pdf (accessed October 23, 2013).

Stiglitz, J oseph E. 1993. The role of the state in financial markets. Taipei: Institute of Economics, Academia Sinica.

Tran, Dac Sinh. 2013. “Nhung doanh nghiep trong VN30 la diem tua niem tin” [VN30 firms are the fulcrum of belief], Dau Tu Chung Khoan, http:/ / tinnhanhchungkhoan.vn/ GL/ N/ DAJ AEC/ nhung-dn-trong-vn30-la-diem-tuaniem-tin.html (accessed October 23, 2013).

Tran, Duc Luong. 2002. “Doi moi - Su lua chon dung dan vi muc tieu phat trien hien dai cua Viet Nam” [Renovation - The right choice for Vietnam's modern development], Communist Review, No. 07, http:// tapchicongsan.org.vn/ data/ tcc/ Html_Data/So_07.html (accessed 22 Oct 2013).

Transparency International. 2013. CPI 2012 and 2013. Berlin: Transparency International.

United Nation Conference on Trade and Development. 2008. Investment Policy Review: Vietnam, New York and Geneva: UNCTAD.

Van Thao. 2009. "Bi Thu Khoan Ho: Nhu Luoi Tam Set [Khoan Ho Party Secretary: Like thunderbolt]," Tuoi Tre, http:// tuoitre.vn/ Chinh-tri-Xa-hoi/ Phong-su-Ky-su/ 311366/ Bithu-\%E2\%80\%9Ckhoan-ho\%E2\%80\%9D---Ky-3-Nhuluoi-tam-set.html (accessed 3 Nov 2013).

VIDS. 2006. The Emerging Civil Society An Initial Assessment of Civil Society in Vietnam. Hanoi: UNDP Vietnam, CIVICUS Civil Society Index.

Vietnam Communist Party. 2011. Chien luoc phat trien kinh te- xa hoi 2011-2020 [Strategy for Socio-Economic Development in 2011-2020], Hanoi: Communist Party of Vietnam.

Viet Dung. 2013. "Doan Van Vuon bi y an 5 nam tu [Doan Van Vuon sentenced 5 years in J ail]," Vnexpress, http:// vnexpress.net/ tin-tuc/ phap-luat/ ongdoan-van-vuon-bi-y-an-5-namtu-2857662.html (accessed December 1, 2013).

Vietnam's MPI and CIEM, FIA, and the USAID. 2007. Assessment of the Five-Year Impact of the U.S.-Vietnam BTA on Vietnam's Trade, Investment, and Economic Structure. Hanoi: National Political Publishing House.

Vietnam National Assembly. 2001. 1992 Amended Constitution. Hanoi: Vietnam National Assembly.

Vietnamnet. 2013. "Tien mac ket, bat dong san con sa lay [Money gets stuck; real estate sector in swamp]" (accessed 15 Oct) http:// vietnamnet.vn/vn/kinhte/ 139149/ tien-mac-ket--bdscon-sa-lay.html 
Vietnam News Agency. 2013. "WB: environmental pollution costs Vietnam 5.5 percent of GDP," Vietnamplus, http:// en.vietnamplus.vn/Home/WBenvironmental-pollution-costsVietnam-55-pct-of-GDP/ 20134/33271.vnplus (accessed 29 Nov 2013).

Vietnam Prime Minister. 2006. Directive 10/ 2006/ CT-TTg. Hanoi: Vietnam Government.

Vuong, Quan Hoang. 2010. Financial markets in Vietnam’s transition economy. Germany: VDM Verlag.

Vuong, Quan Hoang. 2012. “Vietnam's economic challenges,” Stratfor, http:/ / www.stratfor.com/ the-hub/ vietnams-economic-challenges (accessed J anuary 2, 2014).

Vuong, Quan Hoang, and Nancy K. Napier. 2014. "Resource curse or destructive creation in transition: evidence from Vietnam's corporate sector,"Management Research Review, 37(7).

Vuong, Quan Hoang, Nancy K. Napier, Tri Dung Tran, Hong Kong T. Nguyen. 2013. "A categorical data analysis on financial failures in Vietnam, 2007-2013," International J ournal of Business and Management, 8(18), 87-94.

Vuong, Quan Hoang, and Hong Son Nguyen. 2008. "Moi lien thong giua thi truong bat dong san, von va tien te" [Intercorelation between real estate, capital, and money markets], Communist Review, http:// www.tapchicongsan.org.vn/Home/ NghiencuuTraodoi/ 2008/ 1274/Ve-moi-lien-thong-giua-thi-truong-bat-dong-san-vonva.aspx (accessed : 16 Oct 2013).

Vuong, Quan Hoang, Van Nhue Dam, van Houtte Daniel, and Tri Dung Tran. 2011. "The Entrepreneurial Facets as Precursor to Vietnam's Economic Renovation in 1986," The IUP J ournal of Entrepreneurship Development, 8(4).

Vuving, Alexander L. 2008. "Vietnam: Arriving in the World-and at a Crossroads," Southeast Asian Affairs 2008, Institute of Southeast Asian Studies.

Vuving, Alexander L. 2012. “Vietnam's search for stability,” The Diplomat, http:/ / thediplomat.com/2012/ 10/ vietnams-paradoxical-search-forstability/ (accessed December 23, 2013).

Waibel, Michael. 2008. "Implications and challenges of climate change for Vietnam," Pacific News, 29(1).

Waller, Spencer Weber, and Lan Cao. 1996. "Law reform in Vietnam: the uneven legacy of Doi Moi,” N.Y.U. J ournal of International Law and Politics, 29.

Wilson, David J . 2013. “Peacekeeping Partnership Opens New Possibilities for U.S.-Vietnam Relations," U.S. Department of State Official Blog, http:/ / blogs.state.gov/ stories/2013/ 09/ 03/ peacekeeping-partnershipopens-new- 
possibilities-us-vietnam-relations\#sthash.3KJ EHNse.dpuf (accessed November 22, 2013).

World Bank. 2003. “Interview with Vietnam's Prime Minister Phan Van Khai," Transition Newsletter, www.worldbank.org/transitionnewsletter/ aprmayjun03/boxpg35.htm (accessed : 26 Dec 2013).

World Bank. 2008. WB Statistics.

http:// web.worldbank.org/ WBSITE/ EXTERNAL/COUNTRIES/ EASTASIAPACIFICEXT / EXTEAPREGTOPTRANSPORT/0,,contentMDK:21685517 menuPK:574072 pagePK:3 4004173 piPK:34003707 theSitePK:574066,00.html (accessed December 26, 2013). 